\title{
Shared Elements in Destiny between Jewish and Other Ethnic Groups
}

\author{
Jiaming Zhang ${ }^{1, *}$ \\ ${ }^{1}$ Qingdao NO.58 Middle School, Qingdao, Shandong Province 266001, China \\ *Corresponding author e-mail: Dixonzhang03@outlook.com
}

Keywords: Medieval Europe, Antisemitism, Christianity, Crusades, WWII, Genocide, Nationstates, Zionism

\begin{abstract}
The central concern related with the topic is the experienced destiny of Jewish people. The entire paper will mainly focus on the similarity of Jews' destiny with respect to that of other ethnic groups, which requires certain fundamental knowledge about Jewish history and other related time periods. To reach advanced comprehension, researchers are required to make more specific records of history. Under the contemporary background, Jewish people is a distinct group among the whole would, who played an important role in the long history. Thus, we would understand the Jewish people's contribution for the world. The proposed methodology will be used to solve the problem in the passage are historical vertical comparison and horizontal comparison of contemporaries, which significantly highlights the similarity and difference between Jews and other ethnic groups. The result obtained in the research includes the fact that Jewish people shared certain similar destiny with other ethnic groups, but also some essential distinctions in the long-developed history. The comparison mentioned in the passage successfully reflect the distinct destiny of Jewish people, which allows nowadays people get a better understanding of Jewish people, instead of simply regard them as rich people or someone experienced suffer. On the other hand, the entire research and writing process still contain certain drawbacks, which require more historical comparisons to conclude the final result.
\end{abstract}

\section{Introduction}

With the gradual awareness of the importance of Jewish people, it is truly essential to figure out whether or not Jewish people shared destiny with other ethnic groups in the world. However, it is widely accepted that Jewish people nowadays still bear certain discrimination, even though some Jewish people are considered to be rich. Consequently, understanding the history of Jewish people could help people to form a clear sense and comprehension of this ethnic groups, without misunderstanding and bias. For a long period of history, Jewish people shared similar or different destiny with other ethnic groups during Medieval Europe, WWII, and even the contemporary era. Understanding the significance could help people to avoid potential discrimination against particular ethnic groups, which contributes to the coexistence of various ethnic groups in the world.

\section{Methodology}

With the comparative method and the historical analysis of the historical events, the essential similarity will be evidently represented. To view the whole thing in a comparative perspective, we decide to conduct a horizontal comparison to fully show the contradictions of things, that is, the same and different destinies we are exploring, highlighting the essential characteristics of things. In addition, through analyzing in a vertical direction, which is the process of historical development, the changes in people's views of ideas and race can be clearly reflected; in other words, the analysis of time helps to reflect the historical changes and destinies of the nation. Therefore, with the horizontal and vertical comparison and the historical analysis of the Jewish with respect to other ethnic groups, their destinies' similarity and difference can be easy to understand. We will analyze these three periods stated below to support the thesis, including Medieval, WWII, and contemporary. 


\section{Chronological Analysis}

\subsection{Medieval Europe - Black Death and Antisemitism}

Jewish history in Medieval Europe is one of the most remarkable periods that can help analyze its similarity and difference, caused by Antisemitism, with other ethnic groups.

bviously, disease was a big problem during that time for not only Jewish people but everyone in the Medieval Europe. Black death was the most influential disease at that time, causing both danger and even death. Mortality at that time was extremely high, due to the lack of medical treatment. Pyle, Walter Lytle states that "The Black Death resulted in the deaths of up to 75-200 million people in Eurasia and North Africa, peaking in Europe from 1347 to 1351 [1].” Because of the black death, famine showed up at Europe, which also contributed to the mortality rate. Besides, because of the black death, Europe was also affected economically. The burglary rate and crime rate were increased, showing that the lives at that time suffered a hard time due to the diseases. Thus, Jewish people shared a similar fate with other people in Europe during middle age; they were all faced the horrible black death that killed thousands of people's lives in Europe. Additionally, warfare was another essential element of the middle age. Given the several reasons like religious, land conflicting, and states' rights, most states started war frequently, which causes the bad situation for people at that time. Considering the aforementioned factors like diseases, Jewish people experienced certain hard time as the other Medieval European people.

Nevertheless, despite the similarity, Jewish people experienced a different fate with other people at Europe at the middle age: Antisemitism. Antisemitism is the term to reflect the hatred to Jewish people, which showed up as early as the middle age. Jewish people suffered significant rejection from European people at that time. Since most Jewish people were merchandisers during the middle age, Jewish people had to move between different states and areas to maintain their trading. One of the problems Jewish people faced attributed to the rejection of the Christianity, due to the fact the money has a bad representation in Christianity. Owing to the fact that Jewish people have their own belief, which is different from the Christianity belief, it is easily understood that Jewish people were most likely to become traders at that time. Christianity would consider making money immoral based on Bible, but the Jewish people don't listen to the Bible, thus causing other people to have a bad image of Jewish people during the medieval time. Relayed by Jesse Wisnewski about the Bible, "Here's something you need to know about money: Bible verses or not, money is amoral[2]." Therefore, this negative perspective regarding the Jewish people would be considered as a xenophobia, even heretics like monsters. According to the rejections, Jewish people had no choice but to be expelled by almost every state in Europe. In a nutshell, Jewish people were forced to become Christians with the leading of Augustine. It significantly reflects the evolvement of Antisemitism. Because of the difference between Jewish people and Christianity, Antisemitism reached its apex at the end of the middle age, leading the public, Christianity, to force the change in Jewish people, including the crusades. Crusades was a series of military movement instigated by a pope called Urban II in order to "recapture" the lost territory. Because of Antisemitism, Jewish people had different destiny compared to most of the European ethnic groups. Under the influence of Antisemitism, Jews received different treatments, so the destiny of Jews and other groups is different, being discriminated by other ethnic groups.

\subsection{WWII - Genocides}

During the WWII, Jews shared a similar fate with many other ethnic groups in the world. The most known event during that interval was the worldwide genocide: Holocaust for Jewish people. This is due to the fact that Germany needed to pay the enormous war indemnity, which means if they do not have an invasive plan to loot goods and materials directly and fast, they will finally witness the complete collapse of Germany. Achieving this plan can be simply regarded as a "rob," especially the Kristallnacht. Additionally, the Nazi decided to massacre Jewish people with racial separation, which could simply be summarized as Final Solution. "The "Final Solution to the Jewish question" was the official code name for the murder of all Jews within reach, which was not restricted to the European continent.[3]” Because of the genocide, Jewish people were significantly 
affected in both economical and humanistic ways. According to tons of analysis of the genocide, holocaust significantly affected Jewish people economically. This included Jewish people over a wide geographical area. "On the other hand, many Jews, especially young people, began to think of emigration. There were formidable obstacles, caused in large part by the economic depression [4]." One of the most important influences on Jewish people's emigration was their center in the world: from the previous center to Israel and North America. The genocide not only affected the emigration of Jewish people, which means an unstable habitat.

Besides, the genocide also affected the later living (adapting) abilities of Jewish people. Because of the economic difficulties and the emigration burden, Jewish people established a strong ability of adapting to various cultures, which is also a cause of the transformation of the center. Additionally, to widen the scope to the moral level, given that Germany had restricted Jewish people with various laws. German, especially during the Nazi regime, had a long history of bullying Jewish people, which extensively affect the later genocide. "If at least some Germans could kill and beat their neighbors in 1938, then they had already crossed a moral line that, a few years later, made the unthinkable distinctly possible." [4] Besides, Nazi had pressed Jewish to not to revolt. Hitler had mentioned in one of his speeches to Jewish people that "If international finance Jewry inside and outside Europe succeeds in pushing the ethnic groups into a world war, the result will not be the Bolshevization of the earth and with it the victory of Jewry, but the annihilation of the Jewish race in Europe.” [4]

Thus, Jewish people were significantly affected by Nazi in the WWII period with both national discrimination and critical genocide. Worth to mention that people, besides Jewish people during that time, experienced similar destiny with Jews, especially Chinese people.

"Nazi Germany took the lead in the Holocaust but other countries and individuals from other ethnic groups also joined the killing, albeit with varying degrees of enthusiasm and with differing motives that ran the gamut from hatred of Jews, crass opportunism, a desire to curry favor with the Germans, a determination to remove all minorities, and, of course, sheer greed.” [4]

As the quotation mentioned above, other nations, such as the Japanese nation did the similar genocide towards Chinese nation. Chinese nation experienced an almost similar destiny with Jewish people during the WWII. It is no doubt that Chinese experienced a totally inhuman genocide during the WWII, namely War of Resistance against Japan. Japanese forces invading China slaughtered a significant number of Chinese population from 1931-1945, with one of the most notorious cases being the Nanjing Massacre. During the Nanjing Massacre, Japanese force killed almost two hundred to three hundred thousand Chinese citizens in Nanjing city with both humiliation, rape, looting and slaughter. The process also included burial alive, and hence was considered to be a senseless slaughter. This slaughter significantly affected China in social, economic, and culture levels. Socially, the number of people killed is a convincing statistical proof that the Japanese influence on China was terrible. In addition, because of the massacre, the Atrocities of the Japanese army trapped people, leaving them homeless and in constant fear. Economically, the Japanese burned down many buildings and looted half of the houses during the massacre. In addition, homes, shops and workshops were looted, making it a long time for Nanjing to regain its former economic power. Culturally, a wealth of valuable objects with vital historical value were destroyed by Japanese armies. Nanjing is the capital of many ancient dynasties in China, but thousands of years of cultural deposits have disappeared.

\subsection{Contemporary Era-construction of Ethnic Groups and Bearing Discrimination}

With the ever-accelerated booming of the entire world, the tendency that most ethnic groups have their own nation-states is becoming an international well-accepted phenomenon, which being further confirmed by several countries such as China. Every coin has two sides- the trend of globalization among countries reflects another essential influence on both Jewish people and other ethnic groups.

Primarily, the well-known nation, Israel is the nation consist with about $75.5 \%$ of Jewish people, 
which is the unprecedented success in Jewish nation. [5] On 14 May 1948, David Ben-Gurion, who was the head of the Jewish Agency, stated the establishment of a Jewish state in Eretz-Israel, which is known as the State of Israel. That day is just before the expiration of the British Mandate. [6] Jewish people finally achieved their dream of advancing the whole new generation. One of the most essential and transversal theory in the whole process of the reconstruction of country is the Zionism.

"Zionism is both an ideology and nationalist movement among the Jewish people that espouses the re-establishment of and support for a Jewish state in the territory defined as the historic Land of Israel (roughly corresponding to Canaan, the Holy Land, or the region of Palestine).” [7]

With the long period of suffering, it is of great importance to actually contrast the nation state of Jewish ethnic group instead of being expulsion and exclusion by other ethnic groups all over the world, such as the Antisemitism during the Medieval Europe. Initially, a few groups of Jewish people gradually gathered back to Israel, during the late nineteenth century. The first strong tendency of coming back happened in 1881, with the gradually purchasing lands from the Arabs, which paves the future construction of Jewish lands. "People discriminate against Jews because we are not a state," one of the Doctors said. "The only solution to this problem is to establish the Jewish state." Theodor Herzl, developed the idea of calling on Jews all over the world to return to their homeland and restore their way of life, and subsequently started to lead the Zionist movement. [7] With progressively evolving of the Jewish nation, combining with several suffering, oppression, and the general Antisemitism, Israel was finally founded on 1948.05.04, getting rid of being restricted by other ethnic groups. Despite the fact that they experienced the warfare, they still successfully establish the nation.

Even born some difficulties in constructing the sovereign country, Jewish people still reached the most common accomplishment of most ethnic groups all around the world. However, there are actually some small ethnic groups with less attention don't have their own ethnic groups, which contradict with the international tendency.

Additionally, to some ethnic groups, they shared a different destiny with Jewish people during the time they should have their own countries. In contrast, some of the ethnic groups failed to establish their own country. One of the simplest European minorities, Romani, failed to build their own sovereign state. Romani people is an Indo-Aryan ethnic group, living all around the world including mainly Europe and other parts like America. It is widely acknowledged that Romani people are the main consistence of the Europe population for a long period of time. With the historical influence, Romani people gradually suffered a long period of dispersion and wandering. Romani people are usually regarded as unique among all other ethnic groups, owing to that fact that they have never identified themselves with a territory.

"They have no tradition of an ancient and distant homeland from which their ancestors migrated, nor do they claim the right to national sovereignty in any of the lands where they reside. Rather, Romani identity is bound up with the ideal of freedom expressed, in part, in having no ties to a homeland." [8]

However, from the similarity, Romani people shared certain degree of destiny with Jewish with the gradually developing history. Two of the most remarkable events of these two ethnic groups are the genocides and ethnic discrimination. Regardless of being in the WWII period or the contemporary time, these two ethnic groups born similar genocides like the heinous events: WWII Nazi genocides. It is universally acknowledged that holocaust severely stroked and destroyed the Jewish population; the same experience happened on Romani people, as well. Because of the previous discrimination, the final culmination of Anti-Romani hatred came to the apex, which leads Nazi started to think about exterminating Romani people altogether. [8] Besides, as the time passed on to the contemporary era, many countries have promised to ban discrimination based on racial or ethnic origin through strict laws, whereas discrimination against Romani people has not been fundamentally changed. Similarly, Jewish people nowadays is suffering the same destiny. Speech, violence, and human rights are important factors in the Contemporary Antisemitism [9, 10].

\section{Results}




\subsection{The Destiny Similarities and Differences During the Middle Age}

Thereby, Jewish shared similarity with other ethnic groups like disease, whereas Jewish people suffered rejections from European people during the middle age, including economic, social, and religious scale.

\subsection{The Destiny Similarities and Differences During WWII}

Therefore, Chinese shared a similar fate with Jewish people during WWII. Even though carried out by different ethnic groups, genocide targeted Jewish people and Chinese people were both brutal.

\subsection{The Destiny Similarities and Differences at Contemporary World}

In short, it is obvious that, compared with Jewish people, Romani people shared different identity but also some similarity in having their own ethnic groups. Relatively, Jewish people established their country, whereas Romani people didn't.

\section{Conclusion}

In a nutshell, Jewish people shared both different and similar elements in their history with some ethnic groups in specific time period. The Medieval time reflects both the similarity and difference, which includes diseases and discrimination. What's more, because of the distinct religious and ethnic groups' characteristics, Jewish people still shared some different experience in the long-lasting development of the history. Jewish people also have both similar and different destiny with Romani people in contemporary era. Thus, it is undoubtedly true that Jewish is an absolutely critical nation in the history.

\section{References}

[1] Green, Monica H. (2018). "Putting Africa on the Black Death map: Narratives from genetics and history". Afriques (9). doi:10.4000/afriques.2125.

[2] “Bible Verses About Money: 9 Biblical Principles of Money \& Possessions," get.tithe.ly, https://get.tithe.ly/blog/bible-verses-about-money.

[3] Browning i, Christopher (2007). The Origins of the Final Solution: The Evolution of Nazi Jewish Policy, September 1939 - March 1942. U of Nebraska Press. "In a brief two years between the autumn of 1939 and the autumn of 1941, Nazi Jewish policy escalated rapidly from the pre-war policy of forced emigration to the Final Solution as it is now understood - the systematic attempt to murder every last Jew within the German grasp."

[4] Samuel Kassow, THE HOLOCAUST AND ITS AFTERMATH.

[5] Della Pergola, Sergio. Jewish Demographic Policies. The Jewish People Policy Institute. 2011.

[6] Clifford, Clark, "Counsel to the President: A Memoir", 1991, p. 20.

[7] Herzl, Theodor (1988). "Biography, by Alex Bein". Der Judenstaat [The Jewish state]. Translated by Sylvie d'Avigdor (republication ed.). New York: Courier Dover. p. 40.

[8] Grace Badik. Roma: A people without a land. Streetroots, https://www.streetroots.org/news/2013/09/10/roma-people-without-land\#. Accessed 18 September 2020.

[9] UNESCO, Addressing contemporary antisemitism: A global issue? unesco.org. https://en.unesco.org/news/addressing-contemporary-antisemitism-global-issue. Accessed 18 September 2020.

[10] David Wyman, Paper Walls: America and the Refugee Crisis, 1938-1941, 1985. 